\title{
An Academic Review of Employee Behavior Management ${ }^{\mathrm{i}}$
}

\author{
Robin S. McCutcheon \\ Division of Finance \& Economics, Lewis College of Business, Marshall University, USA
}

Copyright $\bigcirc 2018$ by authors, all rights reserved. Authors agree that this article remains permanently open access under the terms of the Creative Commons Attribution License 4.0 International License

\begin{abstract}
The purpose of this paper is to review the origins of behavioral economics and its use in employee behavior management and human resource management theory to impact production and output growth in companies by influencing employee behavior. Early research economists, Oliver Williamson and William Ouchi, used classical labor theory and the theory of the firm to analyze employee behavior management within the firm and within industry structure to determine the most effective way of increasing production output and growth. Their early research prompted the area of behavioral economics. Subsequent researchers in academics outside economics, like sociology and business management, used behavioral economic theory as a springboard to delve into the inner workings of employee behavior management. A close review of this research reveals a dichotomy in employee behavior control. The majority of research has been done in circumstances with enhanced employee behavior control as the premier mode of production output and growth, while too little research has been done under systems employing a more hands-off approach of employee behavior management. The recommendation of this review is that more research in employee behavior management should be done in the latter circumstance.
\end{abstract}

Keywords Personnel Economics, Labor Economics, Labor Management and Worker Empowerment

\section{Introduction}

From time to time, it behooves researchers to review past intellectual contributions to determine their relevance to current paths of academic research. When these reviews are undertaken and published, it contributes to the body of knowledge by way of revealing inappropriately performed methods, or a failure to address other aspects of theory, or to put it plainly, to find holes in current research. Revealing what has not been researched, or has been researched poorly is completely valid and helpful in and of itself to academic research.

In the course of determining why current employee behavior management research is where it is, one must start at the beginning of the path. In the course of reviewing human resource/employee behavior management, one must begin with the seminal research of Williamson and Ouchi. Behavioral economic theory is the outgrowth of a combination of classical labor theory and collectivism by two seminal researchers, Oliver Williamson and William Ouchi. These academics were influenced by business management theory as a way of affecting, or compelling, employee productivity in work groups.

To understand how Williamson and Ouchi tackled their research, a brief review of the foundation of classical labor theory is necessary. The foundation of classical labor theory is that the individual chooses freely to work, or not, for a particular employer and the unit of observation is the individual employee, who is motivated by quantifiable economic incentives, like hourly wages, when choosing to work. Classical labor economists focus on efficient production, or output growth, as a function of the employee's free choice to be more productive based on economic incentives. Because the unit of observation is the individual employee, groups of employees are not viewed as a homogeneous collective. Non-quantifiable job characteristics are considered 'soft data' and are generally not accounted for in classical labor theory.

Beginning in the early 1960s, Oliver Williamson, and later in the 1970s, William Ouchi, using classical labor theory, had a difficult time accounting for changes in dependent variables of worker productivity, or business output growth, using only the hard economic data of wages and weekly hours, and the individual employee as the unit of observation. To fill the gap, Williamson altered the unit of observation from the individual to employees as a collective and began including soft economic data in his independent variables. Williamson's research revolved around the effort by management to control production of output by controlling the collective. Ouchi followed suit in the early 1970s with his own research. 
Williamson's and Ouchi's seminal work committed several sins against classical labor theory, starting with forgetting that individuals have free choice and ending with using various tools (soft data, peer-pressure) to coerce workers to be more efficient and more productive. In the middle is the employee collective, a group that can be pushed around using incentives. You don't have to treat the group well, and the individuals in the group don't really matter because they're just workers. This is the essence of Marxism. The end justifies the means. In this manner they created out of whole cloth the discipline known as behavioral economics. Their research focuses on group control and structure of the firm as the preferred methods to manage a business or output production.

Over the last fifty years, these theories were seized upon by business academics researching solutions to the problem of managing workers in such a way so as to get as much production out of workers as possible.

On the other hand, motivational writers and speakers like Dale Carnegie, Napolean Hill, and Tony Robbins have been around for a hundred years. Their primary goal is to motivate the individual, knowing that the individual's corresponding work group would benefit as well. Few, if any, of their ideas have migrated into theory, or academic research. There is little in academic research with respect to motivating the individual, even though current management practice is trending in this direction.

What would business management and human resource management theory look like if the unit of observation were the individual employee, rather than the group?

\section{A Review of the Literature}

The literature reviewing the topic of employee management is extensive, but seminal research by Oliver Williamson (1963-1981) and William Ouchi, with and without co-authors, (1974-1985), lay the groundwork for management behavior theory and practice by current academic researchers.

\section{Oliver Williamson - Control of Employees via Management}

Williamson was an early observer of the impact economic incentives had on managerial behavior within the firm, and designed the early models of business and employee behavior. [1, 2] The observer to Williamson's work will note that he was unsatisfied at how neoclassical labor theory explained worker behavior once employed, and will note that eventually, he branched into the softer side of management theory. Williamson observed that the internal structure of a firm was at least as important as the structure of the market in which the firm lived. [3] Efficiency and size of the firm, thought by early twentieth century economists like Frank Knight to be impacted by economic incentives, such as wages, was found by Williamson to be more closely associated with types of management and internal organization. [4] He developed models of hierarchical organization, dividing the firm into administration and employees, and used economic models of the Theory of the Firm to determine what, if any, influence the management factor limits the size and efficiency of a firm. [4] Williamson shifted the commonly held beliefs among micro-economists about exterior market transactions to the internal organization of large firms to explain the hierarchical relations within the firm. He posited that market failure occurring in a market could also occur within a firm. [5] But for the existence of humans running firms, he thought economic models would work perfectly to explain the efficiency, or lack thereof, of firms within a market. Ideas such as bounded rationality, opportunism, atmosphere, transactional factors, uncertainty, information asymmetry, administrative and peer group associations advantaging or limiting employees, voice, and firm hierarchy became common research topics among economists, sociologists, and management professors. [5] Remedies to attenuate opportunism using the mechanics of politics within a firm, input management, and collective production, revealed Williamson's particular world-views of persuasion and coercion by managers. Williamson observed that command economies within a firm appeared to work until they didn't. [6]

In 1980 research, Williamson took an in-depth view of the history of modern corporations and allowed that except for the 20th Century M-form (multidivisional) organization, large companies like conglomerate and multinational corporations, were served least by a centralized management system. [7] We leave Williamson in 1981 musing over a statement by Edward Mason from the late 1950 s, the functioning of the corporate system has not to date been adequately explained the man of action may be content with a system that works. [7] This all-encompassing statement makes one think of beehives. Bees do not need humans to help them construct a hive, nor produce honey, nor survive the harsh elements of their surrounding environment, as they have been achieving this phenomenal feat without human aide for thousands of years. What has been the human contribution to the apiary industry? He has merely observed the system and how it functions enough to be able to replicate it without actually knowing how it worked prior to his arrival at the hive.

\section{William Ouchi - Control of Employees via Structure of the Firm}

Ouchi, with various co-authors, began supplanting Williamson's inter-firm research in the early 1970s by focusing on employee behavior, as a group, controlled by the administrative class. Ouchi's research starts by studying the span of control managers have with employees in 1974, but quickly branches to research on direct behavioral 
control and the impact on output by asking should managers control employee behavior or control output. He disputes the commonly held belief that controlling people was a substitute for controlling output (or vice versa). $[8,9]$ In this same body of research, he determines that output measures the control needs of the firm, but behavior control serves the individual needs of managers. Output measures are inappropriate for measuring individual employee performance, and for a small measure of time Ouchi swings towards support of decentralization of control. It does not last, because by 1977, Ouchi focuses on what buttons can be pushed in the worker in order to control them, saying, in order to apply behavior control, the organization must possess at least agreement (buy in by the employee) if not true knowledge, about means-ends relationships. [10] He notes that firm structure is related to control, and that the more levels of hierarchy encompassed by the organization, the more homogeneous tasks are developed within departments. Supervisory efficiency increases with the amount of homogeneous tasks required by employees, and increases the output efficiency of the firm. [10]

Within the environment of 1970s economic stagnation, Ouchi begins studying the Japanese automobile industry and comparing it with the M-form of the U.S. automobile companies. Ouchi re-categorizes the U.S. form of corporation as Type A, and the Japanese form of corporation Type J, but quickly realizes that a combination of both company types would be more efficient in output production primarily due to behavior control of workers. (And, note that somewhere between the early 1970s and the mid-to-late 1970s employees became workers) He names his ideal corporation Type $Z$, which he claims is more efficient primarily because an internal culture encompassing expected behaviors proper to 'company men' were encouraged (and hired in preference to workers displaying anti-company characteristics), economic incentives (such as bonuses and higher wages) were rewarded based on unit performance, and unit cohesiveness was encouraged by developing and promoting a certain type of culture within the company, and thus the company prospered. It is easy to see that Ouchi's Type Z Corporation is an amalgamation of a Japanese and American car company, but admits that there were other America companies that were attaching themselves to the Japanese-way of developing, encouraging, and promoting the 'company culture'. [11-14]

By the end of 1979, Ouchi realigns his Type Z Corporation's behavior control of workers because that type of control is very authoritarian and at a tipping point output efficiency deteriorates. [15] He begins asking how you control people so that they don't know they are being controlled. (What are the mechanisms through which an organization can be managed so that it moves towards its objectives? How can the design of these mechanisms be improved, and what are the limits of each basic design? [15]). The realization that his Type $Z$ Organization has a very command-and-control type of behavior control prompts him to look for other, more subtle ways of worker behavior management. [15] This search leads him to hypothesize three mechanisms: a market mechanism (the economic incentives that persuade a worker to work), a bureaucratic mechanism (the rules and policies of the firm that force a worker to work), and an informal social mechanism (coercion by peer pressure). [15]

\section{Ouchi - Control of Workers via Social Groups}

The informal social mechanism (peer pressure) is reclassified as clans, and in 1980 Ouchi looks at the nature of organizations by asking the question, what is an organization and why do they exist? [16] Careful observation will reveal, if it hasn't already, that both Ouchi and Williamson have a skewed perception of firms, employees and their function, and how efficient markets actually work. In the opening paragraphs, Ouchi misses the basic organization of a free market (where people enter into contracts with each other freely in order to fulfill a need), by taking the filtered view that organizations offer a zero-sum game - 'if someone wins, it's because I lost'. [16] Perhaps it is because the organizations they studied were flawed, or perhaps they held a progressive view of making your employees happy or they'll leave, or the value of the business is how it treats its employees not the value it contributes to its customers, is the dominate view of academics. Williamson and Ouchi forget that while employees are directed to do a job, the employee's personal goal is to receive a wage and unless production and output add to their personal wealth, they don't care what the business goal is.

One notes that in the mid-1980s the U.S. car producers began a program of bonuses and salary incentives linking output and sales to the employee's productive capacity. In Ouchi's 1980 research, the reader may note an interesting statement; an organization such as a corporation exists because it can mediate economic transactions between its members at lower costs than a market mechanism can. Under certain conditions, markets are more efficient because they can mediate without paying the costs of managers, accountants, or personnel departments. Under other conditions, however, a market mechanism becomes so cumbersome that it is less efficient than a bureaucracy. This transactions cost approach explicitly regards efficiency as the fundamental element in determining the nature of organizations. In three sentences, Ouchi convolutes market mechanisms (which Adam Smith named 'the invisible hand') with what people do within the market mechanism. Ouchi clearly doesn't understand what the market mechanism is, or does, or how it works. He was correct in his assumption that minimizing transaction costs is the best way for cooperative organization, but cannot, or won't, realize that the reason the invisible hand works is because no one is controlling it. The market mechanism is 
decentralized. ${ }^{1}$

\section{The Invisible Hand Is the Reason Why Decentralization Works}

A brief explanation of the market mechanism will serve to make the point. In a free market, with many producers (firms, businesses, or suppliers) and many buyers, the forces of Supply and Demand drive the market mechanism, which is the resulting market Price. It is the visibility of the market Price, which anyone in the market sees, that is the disseminator of all information to everyone in the market. The market Price carries within it all of the information in the market, obviating asymmetric information and driving down transactions costs because individuals use the market Price to guide their decisions. Acting in their own best interests, using market Price to make decisions, individuals reach the best outcome for their own self. The decentralization of actions across the populace drives down transactions costs.

No one has to tell participants what to buy (or sell) at any particular price; one need simply look at the price and make a decision. Therefore, the actions of Supply and Demand drive down the market Price to the very lowest possible price. There is no bureaucracy, group of people, or one individual, that could produce any product or service where the market price is lower than one obtained by a free market because the forces of Supply and Demand, being driven by millions of people, is far more efficient than any command and control bureaucracy (large or small).

Just as Williamson observed that market failures occur in the external market and inside a firm, then there must be the same concept of market mechanisms. If there is an external market mechanism (market Price) for goods and services, then there must be an internal market mechanism within the firm for individual employees (hourly wages, bonuses, piece-rate wages, and overtime, to name a few). These internal market mechanisms are akin to the invisible hand observed by Adam Smith in the marketplace. Individual employees use the internal market mechanisms to make decisions in their own best interest as an employee. Employees use the internal market mechanisms to aide their decisions to work more hours (or fewer), work more efficiently, or add their intellectual contributions to productive efficiency of the firm.

Yet, in 1980 Ouchi continues his journey to find the best, most efficient way of managing humans in an organization, without decentralization, and incorporates the idea of 'the clan' within a division or department within the organization. [17] Ouchi thinks clan-led organizations are better because they exert more control than normal typical American organizations because the clan members believe

\footnotetext{
${ }^{1}$ This may be a sticking point among academics, because if the market works without someone actually controlling it, then how is it controlled?
}

in a long-term general equity. [17] The belief in general equity in the long run (meaning, at some point in the future any inequity (abuse) the common worker feels or experiences, will be rewarded, eventually, in the future) allows inequity to happen to workers, singly or collectively. [17] As long as everyone in the group, or organization, buys in to the idea that in the long-run they'll all profit, these busy bee workers are happy to be abused, or suffer abuse in the short-run.

Ouchi mentions that the best organizations with well-developed clan buy-in are companies that have intentionally developed this type of company culture by hiring only people who fit the characteristics of current clan members. [17] It is an intentional path walked by the company for employees are hired only for entry-level positions (so as to inculcate, or indoctrinate, them into their company culture), and then use the company finances to help employees buy homes, cars, etc., in order to foster a culture of co-dependency, so that the employee would never even think about leaving. [17] In this manner, the company finds itself with busy workers forever tied to the company, working only for the company's best interest (because by doing that, one day, some day, the worker too will prosper), and never leave. They are womb to tomb company men.

The notion of 'buy-in' is peculiar to the management and sociology genre of academic research, because in economics 'buy-in' generally means 'an agreement between the employee and the employer such that the employee will provide work, or effort, or expertise, and receive money from the employer.' period. If the worker finds the employer to be odious or the work onerous, the worker is free to leave. The employer can enhance the employees experience to be better or worse, depending on the proclivities of the employer, but, ideally, a smart employer would not drive his workers to leave. Would he? That would be expensive (because hiring and training costs are expensive) and counterproductive (constant turn-over would reduce the company's efficiency and output levels).

Nevertheless, Ouchi comes full circle in his 1985 article organizational Culture? Wherein he asks if culture can be intentionally managed, and owns that the main line of organizational sociology has been focused on doing just that: intentionally controlling culture by regulating social life in organizations. [18] In this historical review, he traces the beginnings of organizational sociology through all its contortions back to the study of organizational culture.

The rest of the literature in this review must be set about, in and around, the research by Williamson and Ouchi and are, in one form or another, concerned with how to persuade or coerce employees to do the job they were hired to do. Researchers use various models, equations, studies, and they pass from the 1980s to the second decade of the 2000s. In the mid-1990s, one noticed that business management transformed into human resources management, and economists demurely ignored the 
non-economic buttons all the while musing why people were not responding to the economic triggers (and asking what else was missing from the model that would make it predict behavior better).

\section{Management and Human Resources (HR) - Controlling Employees via a Smokescreen of Activities}

A serious recognition that the culture within a corporation has an impact on production and output, and the quest for how it can be manipulated is the focus of Barley et al. [19], O'Reilly et al. [20], Sheridan [21], Barker [22], and culminates with three hypotheses of human resource management activities by Arthur [23]. The three hypotheses form the basis for human resource management in academia and are:

1. plants with commitment human resource systems will have better manufacturing performance than plants with control human resource systems;

2. turnover will be higher in control human resource systems than in commitment human resource systems;

3. there will be a stronger negative relationship between turnover level and manufacturing performance in commitment human resource systems than in control human resource systems.

A fourth hypothesis is developed over time with the basic idea is that human resource management schemes using persuasion are preferred to schemes using coercion because the output results are better. Arthur's research swings the academic focus in a slightly different direction with an old refrain with the advent of total quality and management by Dean and Bowen [24].

Huselid's [25] research focuses on systems compelling people to work must be in place, which reinforces the assumption that the worker has little choice in either job selection or company selection, and expands Hypothesis 1 into two parts:

1 a) systems of high performance work practices will diminish employee turnover and increase productivity and corporate financial performance;

1 b) employee turnover and productivity will mediate the relationship between systems of high performance work practices and corporate financial performance

And he alters hypotheses two and three to:

2. Complementarities or synergies among high performance work practices will diminish employee turnover and increase productivity and corporate financial performance;

3. Alignment of a firm's system of high performance work practices with its competitive strategy will diminish employee turnover and increase productivity and corporate financial performance.
Note that all of these hypotheses are concerned with how to keep employees from leaving, which will naturally add to the company's bottom line.

\section{Other Researchers Attempt to Explain How to Control Employees}

A number of researchers take up this refrain with degrees of variation: cognitive diversity leads to cognitive capability leads to correct decisions [26]; inter-company culture has an impact on organizational life and separating the person from his environment and controlling the group will lead to nirvana [27]; progressive human resource management and micromanaging correctly may lead to decentralized decision making [28]; socially complex elements means that cultural and interpersonal relationships are the limitations of management's ability to control workers and output [29]; developing and implementing internally consistent human resource management policies ensure that the collective knowledge, skills, and abilities are the keys to business success [30]; control versus homogeneity (brainwashing in the guise of training and propagandizing) using an historical recounting of scholarly work, but not providing a solution to the human employee problem [31]; an historical review of the captains of industry from 1843 to the mid-twentieth century that provides an nice overview of the journey economists and sociologists have oriented their research [32]; a recognition that managers are important too and have an impact on corporate financial performance [33]; a study on the social preferences in the workplace and whether or not workers internalize the effects of their behavior on coworkers [34]; and a study of the norms of good social conduct and the range within which people cooperate that does not directly have a positive impact on personal outcomes. [35]

Bargaining power and its equivalent bureaucratic control using Slutsky equations with contract curves is used by Miyazaki [36] in a purer form of economic theory, but must be augmented by an economic study of organizational forms, and entry level hiring provides strategic market signaling to firms. [37-39]

The confusion among economists between what's good for the collective versus what's good for the individual is taken up with a study of kin-groups as a form of social control over individuals by a village and an overlapping generations model of social network transfers between generations within villages [40-42]; a melding of psychology and economics in research of the choices individuals make that maximize their utility function and focuses on the values an individual holds dear with a mathematical optimization problem [43]; a study using game theory in decentralized learning of team members and how they cope with the effects of simultaneous learning by other team members [44]; how to use learning-by-doing and its impact on institutional memory when key employees leave their jobs [45]; the question of 
the relationship between economic incentives and social preferences, are they substitutes or complements and how explicit economic incentives are designed to increase contributions to public goods (and promote other pro-social behavior) seem to be counterproductive than would be predicted by self-interested individuals is put forth in 2012 [46]; and social connections and economic efficiency are found to mean that strong social ties are equivalent to control. [47] All of the above authors based their research on contemporary researchers and the mixing of ideas was plentiful. [48-51]

\section{Controlling Employees Using Theories from Sociology}

More recently, Laubach, a sociologist, divides a business in to three types of worker groups: an informal periphery (generally lower level employees that are seen as expendable and easily replaceable), a conventional core (highly committed-to-the-company workers generally low to middle strata employees who probably wouldn't be laid off first, but would still be considered expendable if necessary to the company's viability), and the administrative clan (the ruling elite; generally employees with ties and alliances in every layer of company strata). [52] In this research, he regards autonomy, voice, schedule flexibility and commitment as four sides of a consent deal and uses individuals within their collective group. [52] The consent deal is an informal mode of organizing the workforce such that even should team members be terminated a job can be completely revamped and the remaining team members can be 'reined in' by a new manager without making formal changes to the job description or organizational hierarchy. [52]

The consent deal is basically a multi-level decision tree encompassing the employee's personal characteristics that impact his productive capacity, routes that decision past the next-level managers, and ends with the employee agreeing to be productive in order to gain certain rewards (once again we see that the employee doesn't care for the firm's bottom line as much as he cares about his own bottom line). Laubach starts with the personal work characteristics of the employees in each of the three types of worker groups. These personal work attributes possessed by the worker influence his productive capacity, i.e., if I get to have a say on my hours, then I'll be a good worker? Or if I have a lot of say in how the company is managed, then I'll be a good worker that lead to schedule flexibility or autonomy, which leads to the consent for work. He models a free market form of managing workers, meaning the buyers and sellers are agreeing on the attributes of the product for which they want to trade (in this case they are trading good work for a wage). [52]

Note that, Laubach, as a sociologist, won't give up his collective mindset, but tries to use the individual in a melding of both sides of the coin. His consent deal tries to work with the individual within the collective framework.
There are natural collectives, like bees and ants. The individual bee or ant doesn't think as an individual. People, in groups, still think of themselves as individuals. The fundamental theory motivating sociology is 'we're all a collective' and misses the basic point of individualism; adding in individualism as an afterthought doesn't work. If humans really were collectives, then instinctually, we would organize ourselves to work the way bees and ants do and there would be no need for management. But, we don't.

So, Laubach, from his viewpoint as a sociologist, sees labor management as managing a human collective; he tries not to recognize that people are individuals and fails to recognize the basic human nature of individualism. If individualism crops up in a group of humans, it is perceived as an error and some structure must be created and imposed to force the individuals to behave more like a collective. This contradicts his working philosophy that 'people are already a collective.' Someone in authority must be in charge of the collective. This is where managing an organization originates. Whether or not you use coercion or persuasion, the group must be controlled to get the productive results desired. The theories we review in human resource management, and business management, arise from this latter fundamental thought process.

The art of human management can be stated in two similar ways. The way a sociologist would state human management is that the worker must be persuaded (or perhaps coerced) to 'buy in' to his own exploitation. A classical labor economist would say that human management is involving the employee in the decision making process of production and his part in that process of creating output, which includes the self-interest of the employee. [53]

\section{Discussion}

Over fifty authors were reviewed and the underlying scheme revealed is that designing human resource systems to control employees via the collective is a flawed way to manage employee behavior.

Academics researching employee behavior management offered a number of schemes to 'manage' groups of employees in order to persuade them to work harder, more productively, more efficiently, for the benefit of the company. This review reveals the two ways to manage a workforce: persuasion or coercion. This approach is one-sided, because early researchers relied heavily on collectivist behavior principles conveying the idea that the worker is not a partner in the production process with the business owner.

The subject of employee management has been studied in depth, from multiple stances: individual employee, small groups and departments, entire corporations, using a variety of analytical methods. Economists, sociologists, 
management and human resources professors research what they assumed were ideal policies to implement in order to get employees to work more efficiently, produce more, complain less, contribute to the bottom line, and in short, be the ideal worker.

Little was said about how the individual employee benefits from continued employment.

Past research assumes the worker has no choice in whether to be employed, or not, and receives no benefit from being employed. A fundamental tenant of economics is 'people respond to incentives', where 'people' refers to the individual. This tenant was ignored.

Current pragmatic practice in employee behavior management focuses on individual employee behavior, which ripples outward to improve production and output goals. Clearly over the last four decades management practice has taken a right turn to motivate the individual employee (e.g., human development programs, like the one run by Tony Robbins, are popular), knowing that the downstream effects will benefit the collective, as well.

Academics should be studying current practices and revise their theories accordingly. With the deviation between employee behavior management theories from pragmatic practice, much more research needs to be done on motivating individual employees, rather than the collective, to achieve production results.

\section{REFERENCES}

[1] Williamson, Oliver E. Managerial Discretion and Business Behavior. The American Economic Review, Vol 53, No 5, 1032-1057, 1963.

[2] Williamson, Oliver E. Innovation and Market Structure, Journal of Political Economy, Vol 73, No 1, 67-73, 1965.

[3] Williamson, Oliver E. A Dynamic Theory of Interfirm Behavior, the Quarterly Journal of Economics, Vol 79, No 4, 579-607, 1965.

[4] Williamson, Oliver E. Hierarchical Control and Optimum Firm Size, Journal of Political Economy, Vol 75, No 2, 123-138, 1967.

[5] Williamson, Oliver E. Markets and Hierarchies: Some Elementary Considerations, the American Economic Review, Vol 63, No 2, 316-325, 1973.

[6] Williamson, Oliver E. The Economics of Internal Organization: Exit and Voice in Relation to Markets and Hierarchies, The American Economic Review, Vol 66, No 2, 369-377, 1976

[7] Williamson, Oliver E. The Modern Corporation: Origins, Evolution, Attributes, Journal of Economic Literature, Vol 19, No 4, 1537-1568, 1981.

[8] Ouchi, William G. and John B. Dowling. Defining the Span of Control, Administrative Science Quarterly, Vol 19, 357-365, 1974.

[9] Ouchi, William G. and Mary Ann Maguire. Organizational Control: Two Functions, Administrative Science Quarterly,
Vol 20, 559-569, 1975.

[10] Ouchi, William G. The Relationship between Organizational Structure and Organizational Control, Administrative Science Quarterly, Vol 22, 95-113, 1977.

[11] Ouchi, William G. and Alfred M. Jaeger. Type Z Organization: Stability in the Midst of Mobility, Academy of Management Review, Vol April, 305-314, 1976.

[12] Ouchi, William G. The Transmission of Control through Organizational Hierarchy, Academy of Management Journal, Vol 21, No 2, 173-192, 1978.

[13] Ouchi, William G. and Jerry B. Johnson. Types of Organizational Control and Their Relationship to Emotional Well Being, Administrative Science Quarterly, Vol 23, 160-167, 1978.

[14] Ouchi, William G. and Raymond L. Price. Hierarchies, Clans, and theory Z: A New Perspective on Organization Development, Organization Dynamics a division of American Management Associations, Vol Autumn, 25-44, 1978.

[15] Ouchi, William G. A Conceptual Framework for the Design of Organizational Control Mechanisms, Management Science, Vol 25, No 9, 833-848, 1979.

[16] Ouchi, William G. Markets, Bureaucracies, and Clans, Administrative Science Quarterly, Vol 25, 129-141, 1980.

[17] Ouchi, William G. and Alan L. Wilkins. Efficient Cultures: Exploring the Relationship between Culture and Organizational Performance, Administrative Science Quarterly, Vol 28, 468-481, 1983.

[18] Ouchi, William G. Organizational Culture, Annual Review of Sociology, Vol 11, 57-483, 1985.

[19] Barley, Stephen R., Gordon W. Meyer, and Debra C. Gash. Cultures of Culture: Academics, Practitioners and the Pragmatics of Normative Control, Administrative Science Quarterly, Vol 33, No 1, 24-60, 1988.

[20] O'Reilly III, Charles A., Jennifer Chatman, and David F. Caldwell. People and Organizational Culture: A Profile Comparison Approach to Assessing Person-Organization Fit, The Academy of Management Journal, Vol 34, No 3, 487-516, 1991.

[21] Sheridan, John E. Organizational Culture and Employee Retention, the Academy of Management Journal, Vol 35, No 5, 1036-1056, 1992.

[22] Barker, James R. Tightening the Iron Cage: Concertive Control in Self-managing Teams, Administrative Science Quarterly, Vol 38, No 3, 408-437, 1993.

[23] Arthur, Jeffrey B. Effects of Human Resource Systems on Manufacturing Performance and Turnover, The Academy of Management Journal, Vol 37, No 3, 670-687, 1994.

[24] Dean, James W., and David E. Bowen. Management Theory and Total Quality: Improving Research and Practice through Theory Development, The Academy of Management Review, Vol 19, No 3, 392-418, 1994.

[25] Huselid, Mark A. The Impact of Human Resource Management Practices on Turnover, Productivity, and Corporate Financial Performance, The Academy Management Journal, Vol 38, No 3, 635-672, 1995.

[26] Amason, Allen C. Distinguishing the Effects of Functional 
and Dysfunctional Conflict on Strategic Decision Making: Resolving a Paradox for Top Management Teams, The Academy of Management Journal, Vol 39, No 1, 123-148, 1996.

[27] Denison, Daniel R. What is the Difference between Organizational Culture and Organizational Climate? A Native's Points of View on a Decade of Paradigm Wars, The Academy of Management Review, Vol 21, No 3, 619-654, 1996.

[28] Delaney John T., and Mark A. Huselid. The Impact of Human Resource Management Practices on Perceptions of Organizational Performance, The Academy of Management Journal, Vol 39, No 4, 949-969, 1996.

[29] Becker, Brian and Barry Gerhart. The Impact of Human Resource Management on Organizational Performance: Progress and Prospects, The Academy of Management Journal, Vol 39, No 4, 779-801, 1996.

[30] Huselid, Mark A. Technical and Strategic Human Resource Management Effectiveness as Determinants of Firm Performance, The Academy of Management Journal, Vol 40, No 1, 171-188, 1997.

[31] Mizruchi, Mark S., and Lisa C. Fein. The Social Construction of Organizational Knowledge: A Study of the Uses of Coercive, Mimetic, and Normative Isomorphism, Administrative Science Quarterly, Vol 44, No 4, 653-683, 1999.

[32] Dixon, Robert. Retrospectives: Captains of Industry, the Journal of Economic Perspectives, Vol 16, No 2, 197-206, 2002.

[33] Bertrand, Marianne and Antoinette Schoar. Managing with Style: The Effects of Managers on Firm Policies, The Quarterly Journal of Economics, Vol 118, No 4, 1169-1208, 2003.

[34] Bandiera, Oriana, Iwan Barankay and Imran Rasul. Social Preferences and the Response to Incentives Evidence from Personnel Data, The Quarterly Journal of Economics, Vol 120, No 3, 917-962, 2005.

[35] Tabellini, Guido. The Scope of Cooperation: Values and Incentives, the Quarterly Journal of Economics, Vol 123, No 3, 905-950, 2008.

[36] Miyazaki, Hajime. Labor-Management Bargaining: Contract Curves and Slutsky Equations, Journal of Political Economy, Vol 94, No 6, 1225-1245, 1986.

[37] Maskin, Eric, and Yingyi Qian, and Chenggang Xu. Incentives, Information, and Organizational Form, The Review of Economic Studies, Vol 67, No 2, 359-378, 2000.

[38] Qian, Yingyi, Gérard Roland, and Chenggang Xu. Coordination and Experimentation in M-Form and U-Form Organizations, Journal of Political Economy, Vol 114, No 2, 366-402, 2006.

\footnotetext{
${ }^{\mathrm{i}} \mathrm{JEL}$ codes: M5, J5, M54
}

[39] Pallais, Amanda. Inefficient Hiring in Entry-Level Labor Markets, The American Economic Review, Vol 104, No 11, 3565-3599, 2014.

[40] La Ferrara, Eliana. Kin Groups and Reciprocity: A Model of Credit Transactions in Ghana, The American Economic Review, Vol 93, No 5, 1730-1751, 2003.

[41] Hansen, Morton T. The Search-Transfer Problem: The Role of Weak Ties in Sharing Knowledge across Organization Subunits, Administrative Science Quarterly, Vol 44, No 1, 82-111, 1999.

[42] Townsend, Robert M. Village and Larger Economies: The Theory and Measurement of the Townsend Thai Project, The Journal of Economic Perspectives, Vol 30, No 4, 199-220, 2016.

[43] DellaVigna, Stefano. Psychology and Economics: Evidence from the Field, Journal of Economic Literature, Vol 47, No 2, 315-372, 2009.

[44] Blume, Andreas. , John Duffy and April M. Franco. Decentralized Organizational Learning: An Experimental Investigation, The American Economic Review, Vol 99, No 4, 1178-1205, 2009.

[45] Besanko, David. , Ulrich Doraszelski, Yaroslav Kryukov, and Mark Satterthwaite. Learning-by-doing, Organizational Forgetting, and Industry Dynamics, Econometrica, Vol 78, No 2, 453-508, 2010.

[46] Bowles, Samuel. , and Sandra Polania-Reyes. Economic Incentives and Social Preferences: Substitutes or Complements?, Journal of Economic Literature, Vo1 50, No 2, 368-425, 2012.

[47] Munshi, Kaivan. Community Networks and the Process of Development, the Journal of Economic Perspectives, Vol 28, No 4, 49-76, 2014.

[48] Chan, Andrew. Corporate Culture of a Clan Organization, Management Decision, Vol 35, No 2, 94-99, 1997.

[49] Harrington, Jr., Joseph E. Rigidity of Social Systems, Journal of Political Economy, Vol 107, No 1, 40-64, 1999.

[50] Hofstede, Geert. Cultural Constraints in Management Theories, the Executive, Vol 7, No 1, 81-94, 1993.

[51] Katzner, Donald W. Effort and efficiency in the neoclassical firm, Review of Political Economy, Vol 6, No 1, 62-71, 1994.

[52] Laubach, Marty. Consent, Informal Organization and Job Rewards: a Mixed Methods Analysis, Social Forces, Vol 83, No 4, 1535-1566, 2005.

[53] Becker, Gary S. Human Capital, A Theoretical and Empirical Analysis with Special Reference to Education, Third Edition, The University of Chicago Press, Chicago \& London, 1993 